\title{
注射用エンドキサンの揮発性に関する調査
}

\author{
藪中裕美 ${ }^{* 1}$, 坂口史明 ${ }^{1}$, 小林由佳 ${ }^{2}$, 中西弘和 ${ }^{2,3}$ \\ 塩野義製薬株式会社生産技術本部 CMC 技術研究所 ${ }^{1}$, \\ 京都桂病院薬斉科 ${ }^{2}$, 同志社女子大学薬学部 ${ }^{3}$
}

\section{Investigation on Vaporization of Solution of Endoxan ${ }^{\circledR}$}

\author{
Hiromi Yabunaka ${ }^{* 1}$, Fumiaki Sakaguchi', \\ Yuka Kobayashi ${ }^{2}$ and Hirokazu Nakanishi ${ }^{2,3}$ \\ CMC Development Laboratories, Manufacturing Technology Department, \\ SHIONOGI \& CO., LTD. ${ }^{1}$ \\ Department of Hospital pharmacy, Kyoto Katsura Hospital ${ }^{2}$ \\ Department of Education and Research Center for Pharmacy Practice, \\ Faculty of Pharmaceutical Sciences, Doshisha Women's College of Liberal Arts ${ }^{3}$

$$
\left[\begin{array}{l}
\text { Received December 17, } 2009 \\
\text { Accepted March 2, } 2010
\end{array}\right]
$$ \\ Though antineoplastic agents are widely used in the treatment of cancer, genotoxic carcinogenic antineoplastic agents \\ have mutagenicity and carcinogenicity risks for healthcare workers. A Iso, as it has been reported that higher concentrations \\ of the antineoplastic agent Cyclophosphamide (CPA) were detected in the urine of healthcare workers involved in the \\ preparation and administration of CPA, it has been speculated that they may inhale considerable amounts of CPA. How- \\ This study aimed to clarify the amounts of CPA vaporized from physiological saline solution at different temperatures. \\ The drug solutions were prepared as they would be for treating patients and placed in glass containers, maintaining the so- \\ lutions at $20^{\circ} \mathrm{C}, 25^{\circ} \mathrm{C}, 30^{\circ} \mathrm{C}$ and $40^{\circ} \mathrm{C}$ for 3 hours, respectively, using a temperature controlled water bath. The vaporized \\ CPA was absorbed by the silica gel in an air-sampler, extracted using methanol and quantified by LC/MS. At $30^{\circ} \mathrm{C}$ and 40 \\ ${ }^{\circ} \mathrm{C}$, amounts of vaporized CPA detected were $0.52 \mathrm{ng}$ and $0.93 \mathrm{ng}$, respectively but were below the detection limit (0.16 ng/ \\ $36 \mathrm{~L}$ ) at $20^{\circ} \mathrm{C}$ and $25^{\circ} \mathrm{C}$. Despite these results, however, in consideration of the formation of aerosols during the preparation \\ of CPA solutions, appropriate precautions should still be taken to reduce the risk of exposure to CPA for healthcare work-
} ever, no tests on the vaporization of CPA have been conducted. ers, as described in the guidelines for preparing injection and antineoplastic agents aseptically.

Key words — antineoplastic agents, cyclophosphamide, LC/MS, healthcare workers, vaporization, exposure

緒 言

抗がん薬はがん治療の重要な役割を担っているが, 光 の一方でヒトへの変異原性や発がん性を有するものがあ る.2004 年 National Institute for Occupational Safety and Health から医療従事者へ危険性医薬品の被曝防止にかか わる警告が発表された(http : / www.cdc.gov/niosh/docs/ 2004-165/，2009年11月 10 日アクセス). 実際の抗が ん薬使用にあたっては，医療従事者への被曝防止につい て厳重な管理が必要とされている.わが国においては， 2008年 5 月, 日本病院薬剂師会が『注射剂・抗がん薬 無菌調製ガイドライン』を策定し, 日本の医療事情に 合わせた設備，装置，服装，調製技術などの実際が提示
された .

抗がん薬を含む化学物質の発がん性については,WHO の国際がん研究機関(International Agency for Research on Cancer：IARC)が，ヒトに対する発がん性の危険性の観

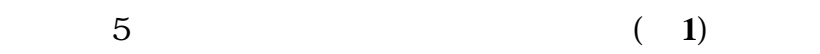
IARC の分類でGroup 1 に含まれている抗がん薬の一つ である Cyclophosphamide(CPA)が海外において，医療従 事者の尿中から検出されたとの報告蛙がり，さらにわ が国でも医療従事者の尿中から CPA が検出されてい $3^{3)}$. 海外の研究結果と比較すると同程度の污染があっ たことが示唆されており，CPA 製剤商品名：注射用工 ンドキサン ${ }^{\circledR}$, 塩野義製薬(株))調製時の曝露, 特に揮発 の危険性が懸念されている．CPA 溶液から CPA が $23^{\circ} \mathrm{C}$ および $37^{\circ} \mathrm{C} て ゙$ 揮発していることを示唆する結果はこれ 
表 1 . 国際がん研究機関(IARC)による発がん性のリスク分類

\begin{tabular}{|c|c|c|c|}
\hline & Group 1 & Group 2A & Group 2B \\
\hline リスク分類 & $\begin{array}{l}\text { ヒトに対する発がん性が } \\
\text { 認められる } \\
(108) \\
\text { carcinogenic to humans }\end{array}$ & $\begin{array}{l}\text { ヒトに対示る発がん性がお } \\
\text { そらくある } \\
(66) \\
\text { probably carcinogenic to } \\
\text { humans }\end{array}$ & $\begin{array}{l}\text { ヒトに対子る発がん性 } \\
\text { が疑われる } \\
(248) \\
\text { possibly carcinogenic } \\
\text { to humans }\end{array}$ \\
\hline $\begin{array}{l}\text { 主な薬品 } \\
\text { 単剤のみ }\end{array}$ & $\begin{array}{l}\text { アザチオプリン } \\
\text { ベンゼン } \\
\text { ブスルファン } \\
\text { シクロスポリン } \\
\text { シクロホスファミド } \\
\text { エチレンオキサイド } \\
\text { ホルムアルデヒド } \\
\text { メルファラン } \\
\text { タモキシフェン } \\
\text { チオラ゙パ } \\
\text { アスベスト }\end{array}$ & $\begin{array}{l}\text { アドリアマイシン } \\
\text { クロラムフェニコール } \\
\text { シスプラチン } \\
\text { エトポシド } \\
\text { ナイトロジェンマスタード } \\
\text { フェナセチン } \\
\text { プロカルバジン }\end{array}$ & $\begin{array}{l}\text { アセトアルデヒド } \\
\text { ブレオマイシン } \\
\text { クロロホルム } \\
\text { ダカルバジン } \\
\text { ダウノマイシン } \\
\text { グリセオフラビン } \\
\text { ヒドラジン } \\
\text { マイトマイシンC } \\
\text { フェノバルビタール } \\
\text { フェニトイン }\end{array}$ \\
\hline
\end{tabular}

IARCでは，発がん性の危険度により Group 1 (ヒトに対する発がん性が認められる; carcinogenic to humans），2A（ヒトに対する発がん性がおそらくある； probably carcinogenic to humans）, 2B（ヒトに対寸る発がん性が疑われる；possibly carcinogenic to humans），3（ヒトに刘する 発がん性があると分類できない; not classifiable as to its carcinogenicity to humans), 4 （ヒトに刘する発がん性が抬そらくなし：probably not carcinogenic to humans）の5つに分類 している.ここでは，Group1，2A，2Bに分類される抗がん薬を示す.

（）内数值は各Groupに分類される化学物質の数安示吉.

までに報告されている゙が，揮発量に関する報告はなさ れていなかった。

本研究では各温度条件における注射用エンドキサン ${ }^{\circledR}$ 溶解液からの揮発の程度を知るため, CPA の揮発量を 測定し，若干の知見を得たのて報告する。

\section{方法}

調剂した注射用エンドキサン『溶解液が安全キャビ ネット内にこぼれて広がり，空気中に揮発したことを想 定して，ビーカーに入れた注射用エンドキサン®溶解液 からの揮発成分(CPA)をエアサンプラーで捕集し, LC/ MS にて測定した .なお，CPA の検出限界は $0.16 \mathrm{ng} / 36 \mathrm{~L}$ であった .

\section{1. 揮発量の測定}

注射用エンドキサン ${ }^{\circledR} 100 \mathrm{mg}$ を生理食塩液 $5 \mathrm{~mL}$ に溶 解させたものをビーカーに移し(液面の面積 $33 \mathrm{~cm}^{2}$ ) , 20 ${ }^{\circ} \mathrm{C}, 25^{\circ} \mathrm{C}, 30^{\circ} \mathrm{C}$ および $40^{\circ} \mathrm{C}\left(20^{\circ} \mathrm{C}, 25^{\circ} \mathrm{C}, 30^{\circ} \mathrm{C}\right.$ は原則 2 回実施し，40 $\mathrm{C}$ は確認のための測定として 1 回測定と した . )に保温した状態で，ビーカーの開口部でエアサ
ンプリングを行った(図 1) . 液面から開口部までの高さ は $12 \mathrm{~cm}$ であった . エアサンプリングにはガラス管にシ リカゲルを 2 層に充填したシリカゲルチューブ(図 2 お よび 3, 柴田科学(株))およびパーソナルエアサンプラー (図 2, 型式PA S-500, 柴田科学(株))を使用し, $200 \mathrm{~mL} /$ 分で 3 時間吸引した . 今回の CPA の揮発性調査におい ては, 万一, 溶液がこぼれた場合等に調製者が吸引する 可能性のある量を明らかにする目的で, ビーカーの表面 を開放状態にしてCPA の揮発量を直接測定する方法を 採用した .なお，エアサンプリングは安全キャビネット 内で排気ファンを止めた状態で行った . エアサンプリン

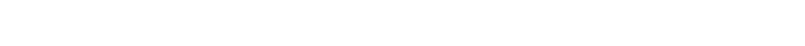
ルを $2 \mathrm{~mL}$ ずつ加えて 30 分間振とうした後, $3000 \mathrm{rpm}$ で15分間遠心分離を行った . 上澄液に塩化ナトリウム の結晶を少量加えて試料溶液とし, 弚の液 1qu に てLC/MSを用いてCPA の定量を行った .

\section{2. 測定機器および測定条件}

LC/MS 装置は, HPLC システム alliance(W aters)および 四重極型質量分析計 micromasszQ(W aters)を用い，正イ 


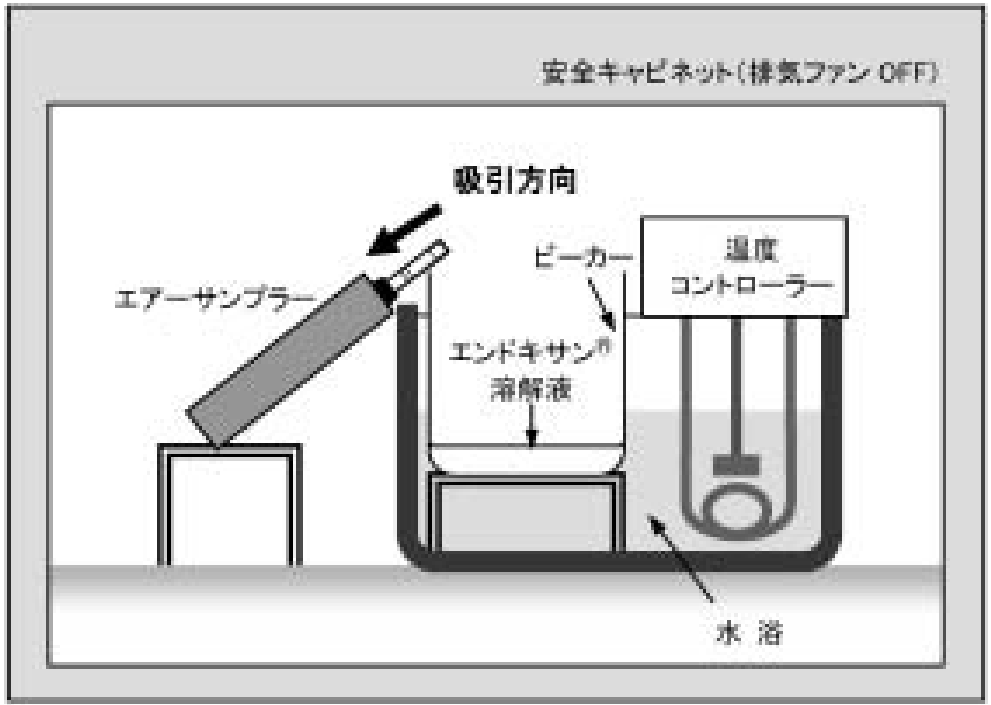

図 1 . 測定方法

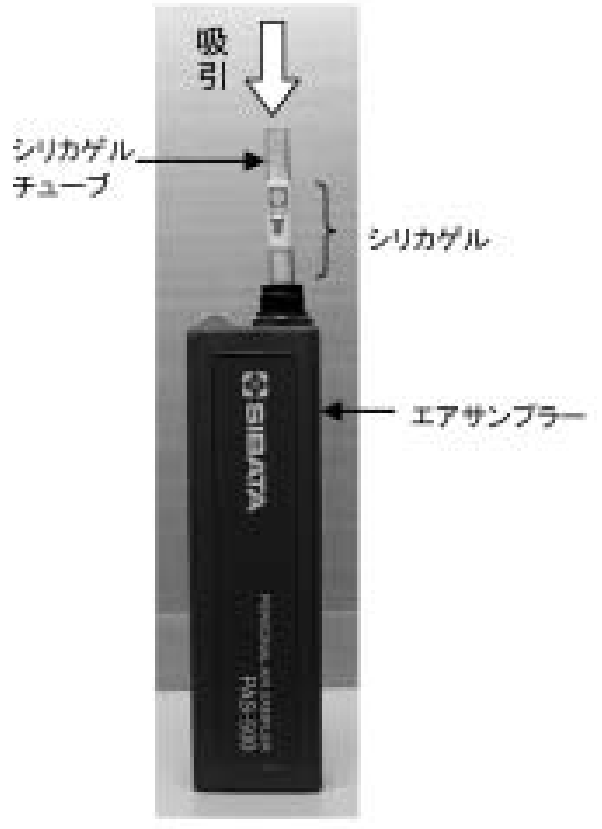

図 2 . シリカゲルチューブおよびエアサンプラー

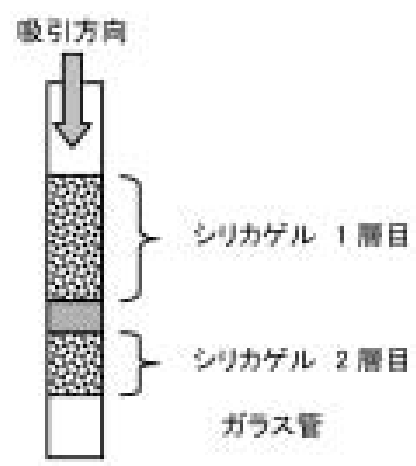

図 3 . シリカゲルチューブの模式図
オン検出エレクトロスプレーイオン化法により測定を 行った . カラムは Cadenza HS-C18(50x 4.6 mm , 3 $\mathrm{m}$ ， Imtakt)を使用し，カラム温度は $35^{\circ} \mathrm{C}$ とした . 移動相は 水/HPLC 用メタノール混液 $(7: 3)$ を使用し 流速 $0.3 \mathrm{~mL} /$ $\min$ とした . またイオン源温度 $120^{\circ} \mathrm{C}$, キャピラリー電 圧 $3 \mathrm{kV}$, コーン電圧 $25 \mathrm{~V}$ とし，検出イオンを $\mathrm{m} / \mathrm{z} 283.1$ $[\mathrm{M}+\mathrm{Na}]^{+}$とする選択イオンモニタリングを行った .

\section{結果}

測定結果を表 2 に示す . $20^{\circ} \mathrm{C}$ おび $25^{\circ} \mathrm{C}$ では検出限 界(0.16ng/36L)未満であり，30C および $40^{\circ} \mathrm{C} て ゙ は ， 3$ 時間で吸引した大気中に光れ攵れ検出限界末満〜0.52 ng および 0.93 ng の CPA が検出された.なお，30Cの条 件では CPA が 0.32 ng 検出された結果と検出限界以下の 結果となったため，3回目の試験を追加した．

\section{考察}

Connor らは CPA 溶液をガラス容器に入れ，細菌を塗 布した培養プレートとともにデシケータに移して蓋を し，閉鎖系で菌への曝露を実施した結果，23C でも CPA が揮発したと報告している゙).これまでCPA の揮 発を示唆する報告はあるものの, 光の揮発量についての 報告がされていなかった .

今回 , 注射用エンドキサン溶解液からの揮発量を測

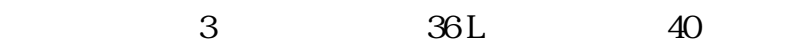
$0.93 \mathrm{ng}, 30^{\circ} \mathrm{C}$ では最大 $0.52 \mathrm{ng}$ の CPA が検出された . 一方， $25^{\circ} \mathrm{C}$ おび $20^{\circ} \mathrm{C} て ゙ は \mathrm{CPA}$ は検出されなかった が吸引時間を延長して, どの程度のCPA が揮発する か, 今後追加試験の実施を検討する必要があると思われ る.また，今回のCPA の揮発性調査においては，注射 用エンドキサン溶解液がさらに広範囲にこぼれた場合 
表 2 . 測定結果

\begin{tabular}{|c|c|c|}
\hline \multirow{2}{*}{ 温度 } & $\begin{array}{c}\text { 繰り返し } \\
\text { (回月) }\end{array}$ & $\begin{array}{c}\text { 捕集した気体 36L 中の } \\
\text { CPA 量 (ng) }\end{array}$ \\
\hline \multirow{2}{*}{$40^{\circ} \mathrm{C}$} & 1 & 0.93 \\
\hline \multirow{3}{*}{$30^{\circ} \mathrm{C}$} & 1 & 0.32 \\
\cline { 2 - 3 } & 2 & N. D. ${ }^{\circ}$ \\
\cline { 2 - 2 } & 3 & 0.52 \\
\hline \multirow{2}{*}{$25^{\circ} \mathrm{C}$} & 1 & \multirow{2}{*}{} \\
\cline { 2 - 2 } & 2 & \multirow{2}{*}{ N. D. $*$} \\
\hline \multirow{2}{*}{$20^{\circ} \mathrm{C}$} & 1 & \multicolumn{2}{|c|}{} \\
\cline { 2 - 2 } & 2 & \\
\hline
\end{tabular}

※ N. D.：36L 中に含まれる CPA の検出限界 $(0.16 \mathrm{ng})$ 术満

を想定し，表面積の広いシャーレ $\left(201 \mathrm{~cm}^{2}\right)$ での揮発量を $20^{\circ} \mathrm{C}$ で同樣に追加試験を行ったが，CPA は検出されな かった(表 2では未提示).

ヒトの分時換気量が6〜9Lであることから，本調査 で測定した $36 \mathrm{~L}$ は最短で 4 分間の換気量となり，注射 用エンドキサン®溶解液の近くで 3 時間調製を行った場 合に吸引する可能性のある量は, 今回の測定值の約 45 倍になることが想定される .

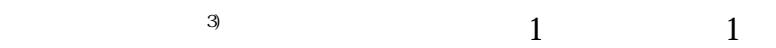
の尿中 CPA 排泄量は 2.7 462.8ng であったとされてお り，CPA の1日の尿中排泄量が被曝量の約 10\% である こどを考慮すれば，実際のCPA の被曝量は光の10倍 程度(27-4628ng)と推察される. 今回の CPA の揮発性調

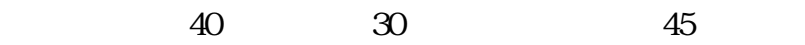
14.4 41.85 ng となる. 鍋島らの報告での推定曝露量の レンジが 27-4628ng であるので, 低い量では同程度で あるが, 高い量に関しては揮発以外の他の曝露要因があ ると示唆される。一方，Sessink らの報告によれば，476 サンプルの 1日当たりの平均尿中排泄量は 0.19 g であ り，ラットの経皮吸収および吸入量は尿中 CPA 排泄量 の 20 倍量であること，ヒトの経皮吸収は尿中 CPA 排泄 量の 100 倍量であると想定すると，医療従事者のCPA の被曝量は 1日当たり 3.6 18 g と算出できると報告し ている、また，この被曝量は医療従事者が一年で 200 日 勤務すると仮定すれば， 40 年間では合計 28.8〜 144 mg のCPA に曝露されているとリスク評価している2゙．医療 従事者のCPA 被曝量と発がん性についてのリスク評価 の報告について自験者らは入手していないが，Bradeら はCPA を投与された患者での膀胱がん発現は平均総投 与量 109〜179g , 平均投与期間 62 89 力月と報告して (る6) . また，総投与量増加とともに有意なリスク上昇 がみられ，CPA 総投与量 $<20 \mathrm{~g}$ での相対危険率は 2.4 , 20〜 49g では $6.3, \geq 50 \mathrm{~g}$ では 14.5 と報告している7 . 治療における 2 次発がん性の評価については個々の症例
の正確なデータ集積と大規模な Cohort study が必要とな り決して容易なことではない，医療従事者の被曝量と発 がん性についての評価は一層難しいが, 被曝量を限りな くゼロにする対策と啓発活動が重要と思われる．今回の 注射用エンドキサン溶解液からの揮発量の測定では， $25^{\circ} \mathrm{C}$ 以下の条件の方が $30^{\circ} \mathrm{C}$ に比べて CPA の揮発量は 低いという結果が得られており，揮発による曝露をでき る限り避けるため，注射用エンドキサン ${ }^{\circledR}$ の調剂は $25^{\circ} \mathrm{C}$ 以下の条件下で実施するのが望ましいと判断する．ま た，溶解液弚のものからの揮発に注意するだけではな く，溶解時のエアロゾルおよび輸液セットを装着する際 に漏れた溶解液等, 調製時および投与時の CPA 污染に ついても注意を払う必要があると考えられる. 実際に， 調剂室だけでなく病棟および病室のCPA 污染が確認さ れており ，付着したCPA に対する接触污染への安全対 策も必要と考えられる .

以上のことから，今回の実験を行った条件と同等であ ればCPA の揮発量はごく微量であることが予測できる が, 調製時はエアロゾルの発生などか認められているこ とより，これで安全と捉えるのではなく，取り扱い時に は『注射剂・抗がん薬無菌調製ガイドライン』等に従い 必要な安全対策を講じるべきと考える。

謝辞 本試験に多大なこ協力を頂きました大阪警察病院 薬 斉部長 山本克己博士に深謝致します。

\section{引用文献}

1)“注射剂・抗がん薬無菌調製ガイドライン”,日本病院薬 剂師会監修，(社)日本病院薬斉師会学術第 3小委員会編 集，薬事日報社，2008, pp. 1-100.

2) P. J. M. Sessink, E. D. Krose, H. J. van Kranen, and R. P. Bos, Cancer risk assessment for health care workers occupa tionally exposed to cyclophosphamide, Int. Arch. Occup. Environ. Health , 67 , 317-323 (1995).

3) 鍋島俊隆, 東海林徹, 杉浦伸一, 谷村学, 中尾誠, 中西 弘和，加藤勝義，無菌調製ガイドラインの配布と抗がん 剂の調製に関するガイドライン策定(抗がん斉の被曝回 避に関する提言)，日本病院薬剂師会雑誌，44，18-20 (2008).

4) T. H. Connor, M. Shults, M. P. Fraser, Determination of the vaporization of solutions of mutagenic antineoplastic agents at 23 and $37^{\circ} \mathrm{C}$ using a desiccator technique, Mutation Research , 470 , 85-92 (2000).

5) T. Wagner, G. Ehniger, Self-induction of Cyclophosphamide and Ifosfamide metabolism by repeated high-dose treatment, Contr. Oncol ., 26 , 69-75 (1987).

6) W. Brade, S. Seeber, K. Herdrich, Comparative activity of ifosfamide and cyclophosphamide, Cancer Chemother. Pharmacol., 18 , S 1-S 9(1986).

7) 山本昇“, がん化学療法の副作用対策”, 西條長宏監修, 中外医学社 , 1998, pp. 172-183. 